\title{
Re-engineering imperatives to enhance the effectiveness of municipal public accounts committees in South African municipalities
}

\begin{tabular}{|c|c|}
\hline \multicolumn{2}{|c|}{$\begin{array}{l}\text { Authors: } \\
\text { Malefetsane A. Mofolo } \\
\text { Vuyo Adonis }\end{array}$} \\
\hline \multicolumn{2}{|c|}{$\begin{array}{l}\text { Affiliations: } \\
{ }^{1} \text { Department of Management } \\
\text { and Governance, Faculty of } \\
\text { Business Sciences, Walter } \\
\text { Sisulu University, East } \\
\text { London, South Africa }\end{array}$} \\
\hline \multicolumn{2}{|c|}{$\begin{array}{l}{ }^{2} \text { Department of Business } \\
\text { Support Studies, Faculty of } \\
\text { Management Sciences, } \\
\text { Central University of } \\
\text { Technology, Bloemfontein, } \\
\text { South Africa }\end{array}$} \\
\hline \multicolumn{2}{|c|}{$\begin{array}{l}\text { Corresponding author: } \\
\text { Malefetsane Mofolo, } \\
\text { drmofolo@gmail.com }\end{array}$} \\
\hline \multicolumn{2}{|c|}{$\begin{array}{l}\text { Dates: } \\
\text { Received: } 16 \text { Nov. } 2020 \\
\text { Accepted: } 18 \text { Mar. } 2021 \\
\text { Published: } 13 \text { May } 2021\end{array}$} \\
\hline \multicolumn{2}{|c|}{$\begin{array}{l}\text { How to cite this article: } \\
\text { Mofolo, M.A. \& Adonis V., } \\
\text { 2021, 'Re-engineering } \\
\text { imperatives to enhance the } \\
\text { effectiveness of municipal } \\
\text { public accounts committees } \\
\text { in South African } \\
\text { municipalities', Africa's } \\
\text { Public Service Delivery } \\
\text { and Performance Review } \\
\text { 9(1), a510. https://doi. } \\
\text { org/10.4102/apsdpr.v9i1.510 }\end{array}$} \\
\hline \multicolumn{2}{|c|}{$\begin{array}{l}\text { Copyright: } \\
\text { (c) 2021. The Authors. } \\
\text { Licensee: AOSIS. This } \\
\text { is licensed under the } \\
\text { Creative Commons } \\
\text { Attribution License. }\end{array}$} \\
\hline \multicolumn{2}{|l|}{ Read online: } \\
\hline 回的回: & $\begin{array}{l}\text { Scan this QR } \\
\text { code with your } \\
\text { smart phone or } \\
\text { mobile device } \\
\text { to read online. }\end{array}$ \\
\hline
\end{tabular}

Background: After 26 years into democracy and 20 years of the new local government operations, the state of the majority of municipalities in South Africa still leaves much to be desired, as they are plagued with maleficence. What is concerning is that these negative tendencies that are troubling local government occur even under the watchful eye of the municipal public accounts committees (MPACs).

Aim: The aim of this study was to evaluate the composition and the role of MPACs, which have experienced a number of challenges since they were introduced in response to the widely held perception of the culture of lack of accountability in South African municipalities.

Methods: This article is theoretical in nature, and it draws its arguments from secondary data in order to understand the composition and the role of MPACs, including its challenges.

Results: This study regards the composition of the MPAC as lacking the necessary vigour to be efficient and effective in executing its duties, particularly when considering the challenges and political influences that it tends to face in its operations.

Conclusion: The study concludes that there is a need for re-engineering of the composition and the role of the MPAC in order to ensure that it executes its functions efficiently and effectively. Consequently, the study recommends three cardinal pillars that must be given attention in re-engineering the MPAC: policy, authority and power.

Keywords: Internal accountability; maleficence; municipalities; municipal public accounts committees; re-engineering.

\section{Introduction}

The role of municipalities in South Africa is indisputable. Just as in any other developing country in the world, municipalities are entrusted with the responsibility of changing the lives of people for the better. Hence, in South Africa, section 152 of the Constitution serves as the bedrock for developmental imperatives that municipalities should realise (Republic of South Africa 1996:74). However, 26 years into democracy and 20 years after the new local government operations, the state of the majority of municipalities in South Africa still leaves much to be desired, as they are plagued with maleficence. In other words, these municipalities, which came into existence on 05 December 2000, are still grappling to realise the constitutional vision of developmental government (De Visser 2009:10).

For instance, the looting of VBS Mutual Bank in 2018, based in Thohoyandou, Limpopo province, South Africa, revealed that there is maleficence practised in some municipalities. Although this is not the focus of this study, what happened is that a number of municipalities in South Africa deposited public funds, supposedly to finance service delivery in their respective communities. These funds were, however, illicitly deposited and invested in the VBS Mutual Bank, against the prescripts of the Municipal Finance Management Act (MFMA) (Republic of South Africa 2003:28-31). In other words, such transactions were done against the law and flagrantly violated the municipal constitutional mandate, as alluded to above.

Of concern is that all these negative developments that afflict local government occur under the watchful eye of all governance structures, including the municipal public accounts committees (MPACs), which have the legislated responsibility of, amongst other things, ensuring internal accountability. Municipal public accounts committees were introduced as a response to the widely held perception of the culture of a lack of accountability in South African municipalities. However, 
because of the political deployment and contestation in municipalities, the oversight capabilities of some MPACs have been undermined. Consequently, in some cases, the MPACs are paralysed (South African Local Government Association [SALGA] 2015:20).

This study therefore focuses on the MPAC as one of the municipal council committees responsible for internal accountability, and established in terms of section 79(1) of the Municipal Structures Act (Republic of South Africa 1998:54). In other words, the MPAC is a committee that is appointed by the municipal council to perform the delegated duties of the council. On the basis of the foregoing, it can therefore be argued that the establishment of the MPAC in municipalities is modelled on the principles of principal agent theory (PA theory). Gailmard (2012:2) points out that accountability forms part of organisations in which principals should consider and assess or evaluate performance of the agents.

The issue of effective accountability in municipalities has been widely considered in the literature. However, apparently, this phenomenon still eludes these public institutions. It is high time that the MPAC, as structured around the principles of PA theory in South African municipalities, should be reengineered in order to address the challenges incidental to accountability. The article is theoretical in nature, and it draws its arguments from secondary data in order to understand the nature and extent of the role of MPAC as a committee that should ensure accountability in municipalities. Therefore, in order to ground and contextualise this study, the PA theory is given attention below.

\section{Principal agent theory: An overview}

According to Waterman and Meier (1998:173), PA models were developed in various disciplines, such as law, finance, accounting and economics. Gauld (2016:1) reveals that, since the advent of PA theory in the 1970s it has had a tremendous influence on the study of Public Administration and its practice, as well as policy. Furthermore, this author indicates that the foundations of PA theory were based on two ideas, which became advocated through the study of the economics of organisational and institutional behaviour.

One of those ideas purports that all spheres of life, including public work, private lives and organisational activities, can be regarded as a set of relationships between different roleplayers (Moe 1984; Perrow 1986, cited in Gauld 2016:2). For operational purposes of such role-players in an organisation like a municipality, Gauld indicates that the details of their relationships, having defined, should be itemised and written into a formal contract, incidental to any particular venture or activity. The contract, in turn, should be used for setting expectations and objectives of role-players and, ultimately, establishing performance assessment and accountability needs. It is on the basis of this view that'contracts are considered as an appropriate means for resource allocation and revealing the scope of the firm's activities (Namazi 2012:40).
In view of the above, Van Slyke (2006) cited in Plaatjies (2016:25850) avers that Agency or PA model is a theoretical framework that is critical for 'structuring and managing contract relationships and to explain the behaviours of principal and agent'. According to Gailmard (2012:3), in PA models, some actor or group of actors called agent(s) undertake an action on behalf of another actor or group of actors called principal(s). In other words, in as far as the practice of PA theory is concerned, the principal delegates tasks to another person, and the agent executes those delegated tasks or activities for the principal (Castillo, Del \& Balbinotto 2017:22).

The practice of PA theory, particularly in the public sector, regards the principal as the legislator that represents the public interest. The agent as an official should carry out some tasks or activities of providing public services on behalf of the principal. Although this could be seen as a perfect operational relationship between the principal and agent, it has been established that sometimes the agent resorts to pursue his or her self-interest, which might not be in the mind of the principal. This is referred to as the 'agency' problem. Principal agent theory claims that the agency problem happens when there is some sort of 'information asymmetry' between the principal and the agent. In other words, this happens when the principal does not know what the agent is doing. This is the matter that should be dealt with through monitoring (Widmalm 2016:131).

Although PA theory is regarded as plausible for monitoring, it is generally not accepted worldwide as an effective tool. For instance, researchers such as Persson, Rothstein and Teorell (2013) cited in Widmalm (2016:132) show scepticism towards PA theory, as they claim that in practice there are instances of a widespread corruption; and to that extent, it may be difficult to find the 'principled principal'. This assertion is critical when one considers the maleficence in South African municipalities as alluded to above and other weaknesses of the theory in the coming sections of this article.

Having considered the above discussions on PA theory, it is appropriate at this juncture to understand the composition and the role of the MPAC.

\section{The composition and role of the municipal public accounts committee}

In the same way as oversight committees in the Parliament are obliged to promote constitutional values of accountability and good governance, as well as control over those laws that have been passed (Mphaisha 2014:88), MPACs in municipalities are envisaged to do the same. As discussed above, MPAC is a committee of the municipal council, which is appointed in accordance with section 79 of the Municipal Structures Act (Republic of South Africa 1998:54). This committee consists of councillors who are appointed from 
the municipal council, and the number of members serving in the committee is not legislated or prescribed. For this reason, each municipality is allowed to determine the number of members that should serve in the committee by taking into consideration the number of councillors in a council. However, no officeholders or executive councillors should serve on the committee. Furthermore, in order to ensure continuity across financial years, it is regarded as ideal that the appointment of members is synchronised with the term of the council (SALGA 2012:8-9).

As far as the role of the MPAC is concerned, it performs functions similar to the Standing Committee on Public Accounts (SCOPA) in the South African Parliament and the provincial legislatures. In this way, MPAC exercises an oversight role on the executive and administration of municipalities, including their entities, in order to ensure good governance and sound financial management. It is therefore expected that MPAC meetings should be open to the public in order to ensure effectiveness of the MPAC. Furthermore, the municipality should ensure that MPAC is supported with financial and human resources, as well as coopt advisory members, who are not councillors in order to execute its functions diligently (Fourie \& Opperman 2015:117; Khalo 2014:217; SALGA 2012:9).

The MPAC is expected to interrogate the following financial aspects in order to ensure compliance with the MFMA:

- unforeseen and unavoidable expenditure (section 29)

- unauthorised, irregular or fruitless and wasteful expenditure (section 32)

- the quarterly report of the mayor on the implementation of the budget and the state of affairs of the municipality or the Service Delivery and Budget Implementation Plan (SDBIP) (section 52(d))

- monthly budget statements (section 71)

- mid-year budget and performance assessment (section 72)

- mid-year budget and performance assessment of municipal entities (section 88)

- disclosures concerning councillors, directors and officials (section 124)

- submission and auditing of annual financial statements (section 126)

- submission of the annual report (section 127)

- oversight report on the annual report (section 129)

- issues raised by the Auditor-General in audit reports (section 131)

- audit committee (section 166)

- disciplinary action instituted in terms of the MFMA (Khalo 2014:217-218; SALGA 2012:10-13).

Although MPAC is charged with other responsibilities as per the Municipal Systems Act (Republic of South Africa 2000:20), the functions shown above suffice for the purposes of this study. All these functions are in line with the MFMA (Republic of South Africa 2003:22), which provides that the municipalities in the country must have norms, standards and other requirements to, amongst other things, ensure transparency, accountability and appropriate lines of responsibility in matters related to their fiscal and financial affairs.

\section{Delegation of roles and responsibilities}

Section 53(1) of the Municipal Systems Act (Republic of South Africa 2000:54) enjoins municipalities to specify the roles and responsibilities of different structures that are established as per the Municipal Structures Act (Republic of South Africa 2000:10). This simply implies that the roles and responsibilities of political structures and officeholders, including municipal managers, must be matters of policy.

It is against this background that section 53(2) of this Act provides that the roles and responsibilities of each political structure and political officeholder, as well as that of the municipal manager, must be clearly defined in writing, and must be acknowledged and be effected in the rules, procedures, instructions, policy statements and other written documents of a municipality. In other words, according to PA theory, such arrangements should be established as contracts that municipal councils enter into with those structures. Furthermore, section 53(5) of the Act stipulates, amongst other things, that when defining the roles and responsibilities of different structures, as shown above, a municipality must decide on their relationship and how they should interact, and, in addition, it should decide on lines of accountability and reporting of those structures.

In view of the above discussions, it is apparent that delegation of responsibilities is the prerogative of the municipal councils (as the main principals) to other political structures established according to the Municipal Structures Act (Republic of South Africa 1998:40-56) and municipal managers, who are heads of the municipal administrations and according to PA theory, are the agents. One could argue that this configuration is to ensure strict internal control and thereby enable municipalities to perform as required. Fourie (2014:283) defines internal control as specific measures, such as reviews, checks and balances, separation of duties, methods and procedures, which are aimed at:

- improving the efficiency of an organisation

- protecting its assets and resources

- preventing errors, fraud and theft

- promoting accurate and complete required accounting data

- generating reliable and accurate financial and management information

- adhering to its policies and plans.

These internal control measures, as defined and shown above, are essential to promote the performance of municipalities, and they also relate to section 195 of the Constitution, which provides for the basic values and principles governing public administration (Republic of 
South Africa 1996:99). Of critical importance for this context is the promotion of efficient, economic and effective use of municipal resources.

\section{Accountability defined}

Most researchers agree to the fact that accountability is fundamental for the achievement of good performance in any organisation (Myeni \& Mvuyana 2015:791). Sindane and Uys (2014:401) indicate that accountability is important, as it ensures ethical behaviour in public administration. Mphaisha (2014:88) also emphasises the importance of accountability by indicating that it encourages transparent governance. Hence, even the South African legal framework and policies advocate the implementation of accountability in the public sector. On the basis of this, it can be argued that one of the basic values and principles governing public administration is that it must be accountable.

Accountability can be defined as an obligation for subordinate officials to explain the success, or failure, of reaching the predetermined organisational goals and objectives through periodical reporting (Risakotta \& Akbar 2018:260). Fourie (2014:271) concurs with the above definition and indicates that accountability relates to the account that individuals should give based on the organisational responsibilities conferred on them. Fourie (2014) explains that accountability concerns itself with the use of organisational resources when institutions and individuals perform their responsibilities. Brynard (2014:375) asserts that accountability is the obligation of an institution or an individual to account for their activities.

From the above definitions, it is evident that there are two ways in which accountability could take place within an organisation, such as a municipality. The first way is external accountability, which can be referred to as public accountability, and the second way is internal accountability. The latter relates to accountability that takes place within an organisation, where subordinates report directly to their authority or supervisors (Risakotta \& Akbar 2018:260-261).

\section{Municipal structures and internal accountability}

Based on previous discussions, it can be said that the structures of the municipalities are organised in a hierarchical manner, and hence the roles and responsibilities are delegated to the lower structures or levels. In fact, municipalities are constituted by communities and political and administrative structures (Sikhakane \& Reddy 2011:86). However, chapter 4 of the Municipal Structures Act (Republic of South Africa 1998:40) clearly provides for the internal structures and functionaries. According to this chapter, the internal structures and functionaries of municipalities are formed by the executive committees in those municipalities that are eligible for the formation of these committees, executive mayors in those municipalities that are empowered as per the Act, other committees of municipal councils and municipal managers (Republic of South Africa 1998:40-56).
In view of the above, it becomes apparent, given the delegation powers of the council, that hierarchically the internal structures of a municipality consist of the council committees (which according to PA theory should execute the PA relationships with other municipal structures on behalf of the council); the executive committee or executive mayor; the municipal manager, who, as shown before, is the head of the administration and an accounting officer. To this end, as internal control benefits were discussed earlier in this study, it can also be deduced that this approach assists to enforce internal accountability relationships amongst these structures, which Sikhakane and Reddy (2011:86) refer to as hierarchical accountability.

As can be seen from the above discussion, internal accountability as a concept and a practice is referred to differently by different researchers. For instance, Myeni and Mvuyana (2015:792) refer to internal accountability as administrative accountability. In their view, administrative accountability relates to an administrative agency's answerability to its supervisory constituencies for the tasks assigned to it. In relation to this, they argue that in most cases administrative tasks include the following:

- compliance with legal frameworks

- conformity to organisational, managerial and financial rules

- fulfilment of organisational goals.

Notwithstanding the terminological variation, alluded to above, the term 'internal accountability' is preferred in this study as the focus is on the MPAC's functions of holding an executive committee or mayor and municipal administration accountable. In other words, the focus is not only on the administration, but also on the organisation. Risakotta and Akbar's (2018:267) study reveals that internal accountability has a positive influence on organisational commitment. This indicates that South African municipalities should regard internal accountability as a tool that should increase organisational performance, and therefore a need for the reengineering of the composition and role of the MPAC, in order to ensure that it executes its functions efficiently and effectively.

\section{Conceptualising re-engineering}

As will be demonstrated below, a number of researchers have given different interpretations and definitions of the concept of 're-engineering'. However, what is common in their definitions is the fact that the re-engineering process focuses on bringing about fundamental changes in business operations and processes in order to ensure the improvement of organisational performance.

Hammer and Champy (1993:90-91, 2009:6) point out that initially re-engineering was referred to as business process re-engineering (BPR). As shown above, its focus was the fundamental rethinking and radical redesign of business processes to achieve dramatic improvements in critical, 
contemporary measures of performance, such as cost, quality, service and speed. Consistent with the foregoing view, Talwar (1993:23) perceives re-engineering as rethinking, restructuring and streamlining of the business structure, processes, methods of working, management systems and external relationships through which value is created and delivered.

Petrozzo and Stepper (1994:30) explain that re-engineering is about the concurrent redesign of processes and organisations and their supporting information systems to achieve radical improvement in time, cost, quality and customer regard for the company's products and services. Lowenthal (1994:39) asserts that the essential components of re-engineering are changing the organisation's core competencies and the achievement of dramatic improvements in organisational performance, through fundamental rethinking and redesign of operating processes and organisational structure.

Given the above definitions, re-engineering can be considered as a redesign of business processes and the associated systems and organisational structures to achieve a dramatic improvement in business performance (Goksoy, Ozsoy \& Vayvay 2012:90; Rigby 2013; Saleema 2012:40). As can be deduced, the common element in all these definitions is to bring about changes in the organisation in order to improve performance, which is the ultimate goal of re-engineering exercise. In the final analysis, one could say that 'reengineering is a planned change'. In other words, reengineering is an intervention exercise that is carried out in order to bring about organisational efficiency and effectiveness. Likewise, re-engineering could also be employed to improve organisational processes and structures.

Although the above discussions on re-engineering focused on business organisations, it should be understood that equally important is that this intervention endeavour is also applicable to local government and other spheres of government in South Africa. It should be realised that since the dawn of democracy, the concept of New Public Management (NPM) has been in South Africa's public sector. The NPM has thus brought a number of management tools that were initially practised in the private sector into the public sector. For instance, operational tools such as planning, monitoring and evaluation, motivation and costbenefit analysis are now part of the public sector as well (Thornhill 2014:19).

Consequently, it is in consideration of the above arguments that this study regards the composition of the MPAC as lacking the necessary vigour to be efficient and effective in executing its duties, particularly when considering the challenges and political influences that this committee tends to face in its operations. A matter that emphasises the criticisms levelled against PA theory, that it is hard to find the 'principled principal'. Therefore, it can be argued that the composition of the MPAC, which is an embodiment of internal accountability in municipalities, should be rethought and redesigned to ensure its efficiency and effectiveness.

In fact, MPACs seem to be experiencing numerous fundamental challenges in South African municipalities. For instance, according to Botlhoko's (2017:233) study, which was conducted in 15 municipalities in the North West province, the empirical findings revealed that some MPAC members were not aware of their responsibilities. In response to the question which sought to establish how effective the MPAC was regarding its oversight role, the above-mentioned study reported that almost half of the respondents (47\%) mentioned that MPAC did not expose or investigate corruption in those municipalities. The study also reported a lack of knowledge about policies and financial management by the respondents.

From the above findings, it becomes apparent that another shortfall in the practice of PA theory is the issue of principals' capacity and capability to execute the functions assigned to them. The educational capacity of some councillors in South African municipalities is not adequate, as most of them possess qualifications that are at the lower levels (ed. Sebola 2015:16). Mofolo (2020:103) also discovered this in his study in one of the municipalities in the Free State province. He discovered that the highest qualifications of the councillors of the ruling party were teaching qualifications, and the lowest qualifications were not even matric.

\section{Re-engineering internal accountability}

It is under the above conditions and others, which were indicated before in the current study, that the MPAC's outlook and character must change for the better. It must not be a business as usual. The MPAC must be strengthened to investigate maleficence, report on it and let those responsible account for their wrongdoing. In this way, MPAC will be functional, effective, efficient and results-driven.

In order to achieve this, re-engineering internal accountability in local government will require an overhaul and reconfiguration of the MPAC. This is necessary to ensure efficiency, effectiveness and accountability in order to realise the set objectives of municipalities in South Africa. It is no secret that accountability in South African municipalities continues to decline. When reporting for the financial year that ended in June 2018, the Auditor-General pointed out that 'the accountability for financial and performance management continues to worsen in most of municipalities' (Auditor-General South Africa 2019:1). It is in this report that it was reported that only 18 municipalities managed to obtain clean audit outcomes.

In his last Municipal Audit Report, namely that of 2018/2019, the Auditor-General painted a bleak picture regarding management of funds that are allocated to municipalities. He indicated that funds are being managed 'in ways that are 
contrary to the prescripts and recognised accounting disciplines' (Auditor-General South Africa 2020:1). He further warned regarding administrative and governance structures that failures in carrying out responsibilities 'make for very weak accountability and the consequent exposure to abuse of the public purse'.

In view of the above, it is evident that three cardinal pillars that must be given attention in re-engineering the MPAC are policy, authority and powers. These issues have a bearing on the effectiveness and impact of the MPAC as a governance structure that must ensure internal accountability. The discussions in the following sections relate to policy reengineering, reconfiguration of authority and the powers of the MPAC

\section{Policy re-engineering}

As shown previously, section 79(1) of the Municipal Structures Act (Republic of South Africa 1998:54) postulates that a council of a municipality may establish one or more committees necessary for the effective and efficient performance of any of its functions or the exercise of any of its powers and appoint the members of such committees from amongst its members. This is the legal basis on which MPACs are established within the context of South African municipalities. Therefore, when the weaknesses and challenges relating to the functioning of the MPAC and the PA theory on which the MPAC is based are considered, as discussed in this article, it becomes imperative that its membership as per the policy should be reconsidered, and as such, amendments should be effected to it. This is a fundamental imperative if this committee is to ensure internal accountability, and thereby promote good governance and performance in these public organisations.

As mentioned above, it cannot be a business as usual in South African municipalities, and nothing is being done. Drastic measures have to be put in place. Even when one considers the earlier reports of the Auditor-General, for example, just the report of 2016/2017 to establish the 3-year historical audit outcomes in relation to those mentioned above, financial statements and the performance of municipalities were not satisfactory at all. This report also shows an exponential increase in irregular expenditure, wasteful expenditure and unauthorised expenditure, despite the presence of MPACs in local government.

It is under these circumstances that this article emphasises that the establishment of the MPAC as per policy needs to be reconsidered, and it calls for the amendment of the policy regarding the membership of the MPAC to ensure its independence. As highlighted before, this can be achieved through the participation of members who are from outside local government, as will be shown in the following section. This approach will allow and condone a principled position that is objective and judicious when dealing with municipal revenues and other resources.

\section{Reconfiguration of authority and the powers of the municipal public accounts committee}

The effectiveness of any structure that plays an oversight role or monitors and evaluates performance can largely be guaranteed by its level of autonomy and independence, that is, its freedom from influence and undue political pressure. This principle applies equally to the MPAC if it is expected to exercise its role and perform its responsibilities optimally.

As with the audit committee, the amendment of the policy is required to ensure that the chairperson of the MPAC is a person who is not employed in a municipality. The majority of the members should also be from outside a municipality. In other words, they should not be employed in municipalities or be part of municipal councils. In reconfiguring the MPAC, perhaps, the intergovernmental relations (IGR) system in South Africa needs to be explored, to allow institutional arrangements and cooperation where local municipalities, districts municipalities and provincial government should constitute the MPAC, in order to ensure its efficiency and effectiveness. Kanyane (2016:94-95) adds that 'the spheres of government should always interplay in the best interest and to the premium benefit of the citizenry'. Tau (2015:804) concurs with this view by arguing that the Constitution requires spheres of government in South Africa to assist and support one another, share information, and coordinate their efforts.

As a committee established by the council, the MPAC must inform the council about its findings and recommendations, but must also have the power to forward those findings and recommendations to the Office of the Auditor-General and the Department of Cooperative Governance and Traditional Affairs (COGTA) at provincial and national levels. It is the view of this article that this approach will effectively establish a culture of accountability for any financial mismanagement in municipalities.

\section{Conclusion}

The main argument of this article is that 26 years into democracy and 20 years after the new local government operations, the state of the majority of municipalities in South Africa still leaves much to be desired, as they are plagued with maleficence. Of great concern is that all these negative developments that afflict local government take place under the watchful eye of all governance structures, including the MPACs, which have the legislated responsibility of, amongst other things, ensuring internal accountability.

However, the findings from the literature provide evidence that the oversight capabilities of MPACs in some municipalities are undermined. Another consideration evident from the literature is that the MPAC consists of councillors who are appointed from the municipal council, and the number of members serving in the committee is not legislated or prescribed. Furthermore, the literature reveals that some MPAC members in a study that was conducted in 
the North West province were not aware of their responsibilities. This above-mentioned study further reported a lack of knowledge about policies and financial management by the respondents who were sampled from the MPACs which formed its population.

This article therefore concludes, citing the literature, that internal accountability has a positive influence on organisational commitment. In relation to this, the article recommends that South African municipalities should regard internal accountability as a tool that should increase organisational performance, and therefore it asserts that there is a need for re-engineering of the composition and the role of the MPAC in order to ensure that it executes its functions efficiently and effectively. In doing so, the article suggests three cardinal pillars that should be given attention in reengineering the MPAC, namely, policy, authority and powers. These issues are considered to be fundamental for the effectiveness and impact of the MPAC as a governance structure that must ensure internal accountability.

\section{Acknowledgements}

The authors acknowledge the scholars whom their work was consulted for compiling this article.

\section{Competing interests}

The authors declare that they have no financial or personal relationships that may have inappropriately influenced them in writing this article.

\section{Authors' contributions}

M.A.M. and V.A. contributed equally to this article.

\section{Ethical considerations}

This article followed all ethical standards for a research without direct contact with human or animal subjects.

\section{Funding information}

This study received no specific grant from any funding agency in the public, commercial or not-for-profit sectors.

\section{Data availability}

The authors confirm that the data supporting the findings of this study are available within the article.

\section{Disclaimer}

The views and opinions expressed in this article are those of the authors and do not necessarily reflect the official policy or position of any affiliated agency of the authors.

\section{References}

Auditor-General South Africa, 2019, Media release, viewed 10 September 2020 from https://www.agsa.co.za/Portals/0/Reports/MFMA/2019.06.25/2019\%20 MFMA\%20Media\%20Release.pdf.
Auditor-General South Africa, 2020, Media release, viewed 01 July 2020, from https://www.agsa co.za/Portals/0/Reports/MFMA/201819/Media\%20 Release/2020\%20MFMA\%20Media\%20Release\%20Final.pdf.

Botlhoko, T.S., 2017, 'Promoting effective financial accountability in local government in the North West province: Developing operational guidelines for municipal public accounts committees', Doctoral thesis, Central University of Technology, Free State, Bloemfontein.

Brynard, D.J., 2014, 'Administrative justice in the contemporary state', in C. Thornhill, G. Van Duk \& I. Ile (eds.), Public administration and management in South Africa: A developmental perspective, pp. 374-386, Oxford University Press Southern Africa, Cape Town.

Castillo, M., Del, P. \& Balbinotto N.G., 2017, 'A model of desertion. From a principalagent theory perspective', Cuadernos de Economía 36(70), 19-47. https://doi. org/10.15446/cuad.econ.v36n70.44316

De Visser, J., 2009, 'Developmental local government in South Africa: Institutional fault lines', Commonwealth Journal of Local Governance 2(1), 7-25.

Fourie, D., 2014, 'Improving budgeting and financial management', in C. Thornhill, G. Van Duk \& I. Ile (eds.), Public administration and management in South Africa: A developmental perspective, pp. 270-294, Oxford University Press Southern Africa, Cape Town.

Fourie, M. \& Opperman, L., 2015, Municipal finance and accounting, 3rd edn., Van Schaik, Pretoria.

Gailmard, S., 2012, Accountability and principal-agent models, viewed 03 May 2020, from https://www.law.berkeley.edu/files/csls/Gailmard__ Accountability_and Principal-Agent_Models(2).pdf.

Gauld, R., 2016, 'Principal-agent theory of organizations', in A. Farazmand (ed.), Global encyclopedia of public administration, public policy, and governance, Springer, Cham. https://doi.org/10.1007/978-3-319-31816-5_72-1

Goksoy, A., Ozsoy, B. \& Vayvay, O., 2012, 'Business process reengineering: Strategic tool for managing organizational change an application in a multinational company', International Journal of Business and Management 7(2), 89-112. https://doi.org/10.5539/ijbm.v7n2p89

Hammer, M. \& Champy, J., 1993, 'Reengineering the corporation: A manifesto for business revolution', Business Horizons 36(5), 90-91.

Hammer, M. \& Champy, J., 2009, Reengineering the corporation: Manifesto for business revolution, Harper Collins, New York, NY.

Kanyane, M., 2016, 'Interplay of intergovernmental relations conundrum', in D. Plaatjies, M. Chitiga-Mabugu, C. Hongoro, T. Meyiwa, M. Nkondo \& F. Nyamnjoh (eds.), State of the Nation South Africa 2016: Who is in charge?: Mandates, accountability and of the Nation South Africa 2016: Who is in charge?: Mandates, accountability an
contestations in the South African state, pp. 92-106, HSRC Press, Cape Town.

Khalo, T., 2014, 'Municipal financial management', in E. Nealer, D. Van Niekerk, T. Khalo, K. Phutiagae, C. Van Der Walt, A. Venter et al. (eds.), Municipal management: Serving the people, 2nd edn., pp. 204-224, Juta, Cape Town.

Lowenthal, J.N., 1994, Reengineering the organization. A step-by-Step approach to corporate revitalization, ASQ Quality Press, Milwaukee, WI.

Mofolo, M.A., 2020, 'Ubiquity of qualified audits in South African municipalities: Case of category B municipality in the Free State Province', Journal of Public Administration and Development Alternatives 5(1), 95-109.

Mphaisha, C., 2014, 'Functioning between the branches of government: Ensuring democracy', in C. Thornhill, G. Van Duk \& I. Ile (eds.), Public administration and management in South Africa: A developmental perspective, pp. 75-104, Oxford University Press Southern Africa, Cape Town.

Myeni, S.L. \& Mvuyana, B.Y.C., 2015, 'Rethinking administrative accountability and the rule of law in housing development in South Africa', Journal of Public Administration 50(4), 788-800.

Namazi, M., 2012, 'Role of the agency theory in implementing management's control', Journal of Accounting and Taxation 5(2), 38-47. https://doi.org/10.5897/ JAT11.032

Petrozzo, D.P. \& Stepper, J.C., 1994, Successful reengineering, Van Nostrand Reinhold, New York, NY.

Plaatjies, D., 2016, 'The principal-agent model in public service education, training and professional development', International Journal of Current Research 8(1), 25848-25858.

Republic of South Africa, 1996, Constitution of the Republic of South Africa, 1996 (Act no. 108 of 1996), Government Printer, Pretoria.

Republic of South Africa, 1998, Municipal Structures Act (Act No. 117 of 1998), Government Printer, Pretoria.

Republic of South Africa, 2000, Municipal Systems Act (Act No. 32 of 2000), Government Printer, Pretoria.

Republic of South Africa, 2003, Municipal Finance Management Act (Act No. 56 of 2003), Government Printer, Pretoria.

Rigby, K.D., 2013, Management tools: An executive's guide, Bain \& Company, Boston, MA.

Risakotta, K.A. \& Akbar, R., 2018, 'The effective of internal and external accountability, job motivation and education on local government officials' performance', Journal of Indonesian Economy and Business 33(3), 257-272. https://doi.org/10.22146/ jieb.13921

Saleema, P.M., 2012, Contemporary office handbook, DC Books, Kottayam.

South African Local Government Association (SALGA), 2012, Municipal Public Accounts Committee (MPAC): Enhancing oversight in the municipality, viewed 26 June 2020 from http://www.salga.org.za/Documents/Municipalities/Municipla\%20Focus/ Municipal\%20Public\%20Accounts\%20Committee\%20MPAC/MPAC-guide-final.pdf 
South African Local Government Association (SALGA), 2015, SALGA National members assembly discussion documents, viewed 15 August 2020, from http://www.salga. org.za/Documents/NMA\%20Documents\%202016/SALGA\%20Discussion\%20 Documents.pdf.

Sebola, M.P. (ed.), 2015, Local government administration in post-apartheid South Africa: Some critical perspectives, Batalea Publishers, Polokwane.

Sikhakane, B.H. \& Reddy, P.S., 2011, 'Public accountability at the local government sphere in South Africa', African Journal of Public Affairs 4(1), 85-102.

Sindane, A.M. \& Uys, F., 2014, 'Maintaining ethical conduct in public administration', in C. Thornhill, G. Van Duk \& I. Ile (eds.), Public administration and management in South Africa: A developmental perspective, pp. 392-411, Oxford University Press Southern Africa, Cape Town.
Talwar, R., 1993, 'Business re-engineering. A strategy-driven approach', Long Range Planning 26(6), 22-40. https://doi.org/10.1016/0024-6301(93)90204-S

Tau, M.L., 2015, 'Intergovernmental relations and cooperative governance in South Africa: Challenges and prospects', Journal of Public Administration 50(4), 801-823.

Thornhill, C., 2014, 'The development of the discipline of public administration', in C. Thornhill, G. Van Duk \& I. Ile (eds.), Public administration and management in South Africa: A developmental perspective, pp. 3-24, Oxford University Pres Southern Africa, Cape Town.

Waterman, R.W. \& Meier, K.J., 1998, 'Principal-agent models: An expansion?', Journa of Public Administration Research and Theory 8(2), 173-202.

Widmalm, S., 2016, After NPM, curb your enthusiasm for the Principal Agent theory, viewed 02 August 2020, from file:///C:/Users/staff/Documents/Principal-agent $\% 20$ theory $\% 202$.pdf 